\title{
Framing Berita Media Online terhadap Kinerja Pemerintah dalam Menanggulangi Tingginya Kasus PHK di Masa Pandemi COVID - 19
}

\author{
Tasya Fasa ${ }^{1}$, Shavira Amellia ${ }^{2}$, Ika Novita ${ }^{3}$, Saifuddin Zuhri ${ }^{4}$ \\ 1,2,3,4 Program Studi Ilmu Komunikasi, UPN "Veteran" Jawa Timur \\ Email : anjanitasya0@gmail.com
}

\begin{abstract}
The occurrence of the Covid-19 pandemic has brought many changes globally, losses from various sectors are also felt by the Indonesian people, especially in the field of labor, which is currently experiencing a decline in turnover at each company. Online media news portals are a tool for the public to find out information about the spread of the Covid-19 outbreak, especially related to the government's performance in dealing with the spike in unemployment that is currently happening due to the many actions in the form of layoffs (layoffs). The purpose of this study was to describe the online media news framing related to the effectiveness of government performance in overcoming the high number of layoffs in Indonesia. The research method used is the Robert M. Entman framing analysis method, with the object of research from two news portals that discuss the government's performance in dealing with a spike in layoffs (PHK) at Tirto.id and CNN Indonesia. The results show that both Tirto.id and CNN Indonesia show the positive and negative sides of the problem, but what is quite visible is the negative side of the statement and also the criticism that is included in the content of the news, while CNN Indonesia in packaging news about the problem from the pro and counter. But what is more visible is the pro side.
\end{abstract}

Keywords: Framing Analysis, News, Covid-19, Online media, layoffs.

\begin{abstract}
Abstrak. Terjadinya pandemi covid-19 telah banyak membawa perubahan secara global, kerugian dari berbagai sektor ikut dirasakan oleh masyarakat Indonesia khususnya dalam bidang tenaga kerja yang saat ini mengalami penurunan omset pada setiap perusahaan. Portal berita media online menjadi alat masyarakat untuk mengetahui informasi mengenai penyebaran wabah covid-19 terutama terkait dengan kinerja pemerintah dalam menangani lonjakan pengangguran yang saat ini sedang terjadi akibat banyaknya tindakan berupa pemutusan hubungan kerja (PHK). Tujuan penelitian ini adalah untuk mendeksripsikan framing berita media online terkait dengan efektivitas kinerja pemerintah dalam menanggulangi tingginya kasus PHK di Indonesia. Metode penelitian yang digunakan yaitu metode analisis framing Robert M. Entman, dengan objek penelitian dari dua portal berita yang membahas kinerja pemerintah dalam menghadapi lonjakan pemutusan hubungan kerja (PHK) pada Tirto.id dan CNN Indonesia. Hasil penelitian menunjukkan bahwa baik Tirto.id maupun CNN Indonesia memperlihatkan sisi positif dan negatif dari masalah tersebut, namun yang cukup terlihat yaitu sisi negatif dari pernyataan dan juga kritik yang dimasukkan dalam isi beritanya sedangkan CNN Indonesia dalam mengemas berita mengenai masalah tersebut dari sisi pro dan kontra. Namun yang lebih terlihat yaitu sisi pro.
\end{abstract}

Kata Kunci : Analisis Framing, Berita, Covid-19, Media online, PHK.

\section{PENDAHULUAN}

Pandemi Covid-19 atau yang dikenal sebagai virus korona telah menyerang hampir seluruh belahan dunia. Secara history, pandemi covid-19 merupakan penyakit menular berupa virus yang ditemukan pada tahun 2019 yang hingga saat ini masih menjadi permasalahan utama tiap - tiap negara. Virus ini pertama kali ditemukan di Wuhan, Tiongkok yang disebabkan oleh penularan virus hewan liar yaitu kelelawar. Hingga saat ini tercatat di worldometers.com sebanyak 36,2 juta kasus positif corona di seluruh dunia dengan kematian mencapai 1,06 juta jiwa. Sedangkan di Indonesia mencapai 321 ribu kasus positif dan masih bertambah setiap harinya. 
Adanya pandemik virus covid-19 ini tidak hanya berdampak pada meningkatnya angka kematian secara drastis, namun juga sangat mempengaruhi sector perekonomian, bahkan hingga sektor pendidikan di Indonesia. Dampak kerugian yang cukup signifikan terjadi terutama dibidang perekonomian. Masyarakat yang terpaksa harus membatasi kegiatan mereka di luar rumah karena himbauan pemerintah yang bertujuan untuk menurunkan tingkat kasus positif rupanya menganggu masyarakat dalam bekerja. Seperti yang dapat kita lihat saat ini, banyak sekali industri yang collapse dan bahkan gulung tikar yang berimbas pada Pemutusan Hubungan Kerja (PHK) bagi sebagian masyarakat.

Selain berusaha menurunkan angka kasus positive virus Covid-19, hal ini seharusnya menjadi fokus atau prioritas pemerintah Indonesia, mengingat banyak sekali buruh atau pekerja yang kehilangan pekerjaan mereka sehingga kesejahteraan pangan mereka tidak stabil. Dalam menanggapi hal ini, pemerintah mengambil beberapa tindakan guna membantu masyarakat dikondisi genting seperti sekarang ini.

Media massa menjadi alat informasi pemerintah yang berfungsi sebagai jembatan antara masyarakat dan pemerintah berperan sangat besar di saat kondisi pandemic Covid-19. Seperti yang kita ketahui bahwa media massa saat ini menjadi alat informasi utama publik dalam menerima informasi seputar pandemi Covid-19. Hal - hal mengenai pandemi, hingga gerak gerik pemerintah dalam menindak kasus ini sangat disorot oleh media massa.

Akibat dari adanya pandemi virus corona yang hampir mendunia, kerugian juga mulai dirasakan masyarakat karena adanya lonjakan tingkat pengangguran di Indonesia yang semakin meningkat. Bappenas menyebutkan bahwa tingkat kenaikan pengangguran Indonesia mencapai 3,7 juta orang dengan kenaikan sebesar 50\% . Manager Jobstreet Faridah Lim mengatakan bahwa "Kami banyak melihat informasi. Diprediksi, akhir tahun ini pengangguran bakal meningkat 4 juta-5 juta sehingga akan mencapai 11 juta. Ini adalah angka yang sangat signifikan," sektor pekerja yang paling terdampak yaitu dari Hospitality, Pariwisata, tekstil, makanan dan minuman, dan arsitektur. Tentu saja hal ini menjadi konsentrasi pemerintah yang sangat diprioritaskan hingga menghasilkan beberapa tindakan salah satunya yaitu "new normal" yang diharapkan dapat memperbaiki kondisi pekerja di Indonesia khususnya dalam masa pandemic covid - 19 ini.

Tindakan lain berupa bantuan dana, APD, menyediakan fasilitas medis juga dilakukan oleh pemerintah Indonesia. Namun masih banyak pula masyarakat yang menganggap bahwa pemerintah kurang tanggap dalam menangani pandemic ini. munculnya berbagai pemberitaan di media massa tentu juga sangat berpengaruh terhadap penilaian masyarakat. Pemberitaan yang seperti apa? Apakah berita - berita dengan judul yang unik dan kontroversial?

Tujuan Penelian ini adalah untuk melihat bagaimana sudut pandang media massa dalam mengolah sebuah fakta khususnya mengenai kinerja pemerintah dalam menanggulangi tingginya kasus PHK di masa Pandemi Covid-19. Jurnal ini dibuat dengan memiliki referensi jurnal terdahulu yaitu "Framing Berita Online Tentang Dugaan Eksploitasi Anak pada Calon Atlet Bulu Tangkis PB Djarum" yang dibuat oleh Cintia Maryanih dan Indah Suryawati. Topik yang kami angkat dalam jurnal kali ini juga untuk memberikan novelty (Kebaruan) dengan memasukkan "Covid-19” sebagai kebaruan tersebut.

Seperti yang kita ketahui juga bahwa CNN News dan Tirto.id sudah menjadi salah satu portal media online yang cukup popular dan digemari masyarakat karena factual dan aktualitasnya dalam mengelola dan memberikan suatu informasi berupa News / berita. Dari sini kami sebagai peneliti ingin mengetahui bagaimana kedua portal berita tersebut membingkai suatu realitas atau peristiwa yang terjadi di masyarakat. 
Dengan menggunakan teknik penelitian kualitatif analisis framing, peneliti ingin mengungkap bagaimana tindakan pemerintah dalam menangani pandemic ini melalui perspektif atau kacamata media massa dengan meninjau teks atau kebahasaan yang ada di berita - berita portal media massa dan membandingkan dua diantaranya dalam jangka waktu Juni hingga September, untuk mengetahui bagaimana framing yang dilakukan oleh masing - masing portal berita online tersebut.

\section{METODE PENELITIAN}

Metode peneliatan yang digunakan dalam penelitian ini adalah penelitian kualitatif, dalam penelitian kualitatif lebih mengutamakan bagaimana realitas yang dibangun secara sosial. Model analisis dalam penelitian ini yaitu menggunakan analisis framing. Analisis framing dalam penelitian ini digunakan untuk melihat bagaimana cara media memaknai, memahami dan membingkai kasus atau peristiwa yang diberitakan oleh kedua portal berita online, yaitu CNN Indonesia dan Tirto.id.

Metode semacam ini berusaha menafsirkan makna dari suatu teks dengan menguraikan bagaimana media membingkai isu, pemberian definisi, penjelasan, evaluasi, karena peristiwa yang sama akan memungkinkan untuk dibingkai berbeda oleh media (Eriyanto, 2018). Penelitian kali ini menggunakan alasisis framing menurut Robert M. Entman yang telah banyak digunakan dalam penelitian-penelitian sebelumnya. Terdapat dua dimensi besar dalam framing Entman yaitu, mengenai seleksi isu dan penonjolan aspek-aspek tertentu. Kedua faktor ini untuk mempertajam framing berita yang ditampilkan dan penekanan isi beritanya.

Selain dua dimensi besar tersebut, terdapat empat tahapan bagaimana framing dilakukan dalam sebuah berita, yang pertama yaitu pendefinisian masalah mengenai bagaimana peristiwa tersebut dipahami oleh wartawan. Kedua, memperkirakan penyebab masalah, berkaitan dengan seperti apa dan siapa saja aktornya. Ketiga, Make moral judgement atau membuat pilihan moral, dan keempat yaitu menekankan penyelesaian, hal ini untuk menilai apa yang dikehendaki oleh wartawan.

Berita yang akan digunakan antara lain,

1. “Angka Pengangguran 2020 Terburuk, Apa yang Bisa Dilakukan Jokowi?” oleh Tirto.id , pada 24 Juni 2020.

2. "Dampak COVID-19, Airlangga: Korban PHK Indonesia Naik Jadi 2,1 Juta" oleh Tirto.id, pada 12 Agustus 2020.

3. "Berbagai Insentif Jokowi Saat Pandemi yang Telat dan Kurang Tepat" oleh Tirto.id, pada 1 September 2020.

4. "Pekerja Dirumahkan dan Kena PHK Akibat Corona Capai 3,05 Juta" oleh CNN Indonesia , pada 20 Juli 2020.

5. "Setelah Beri BLT Pekerja, Jokowi Perlu Revisi Kartu Prakerja" oleh CNN Indonesia, pada 27 Agustus 2020.

Peneliti dalam hal ini menggunakan teknik analisis data dengan pendekatan analisis deskriptif. Di mana nantinya akan digambarkan hasil temuan data baik kata-kata maupun gambar pada objek penelitian, yang selanjutnya akan dideskripsikan dalam tulisan ilmiah.

\section{HASIL DAN PEMBAHASAN}

Berita memiliki salah satu fungsi untuk memberikan edukasi dan kesadaran terhadap khalayak mengenai isu-isu dan peristiwa yang terjadi, sehingga masyarakat lebih mengerti dan memahami berbagai 
kejadian atau peristiwa. Hal tersebut berkaitan dengan bagaimana media mengkonstruksikan suatu realitas dalam bentuk wacana yang yang bermakna, karena sejatinya menurut Gaye Tuchman peristiwa yang ditampilkan oleh media yang sebelumnya dikonstruksikan oleh media tersebut berdasarkan penyusunan realitas-realitas hingga membentuk sebuah cerita atau wacana (Sobur, 2014).

Sebuah portal berita dalam menyusun realitas dari berbagai peristiwa yang terjadi hingga menjadi cerita atau wacana yang bermakna. Dalam proses konstruksi realitas oleh sebuah portal berita, tentunya memiliki sudut pandang sendiri-sendiri ketika melihat suatu peristiwa, salah satunya bahasa, dimana bahasa adalah unsur utama. Bahasa merupakan alat konseptualisasi dan alat narasi. Penggunaan bahasa merupakan simbol tertentu untuk menentukan format narasi dan makna tertentu yang ingin bingkai oleh sebuah portal berita.

Dalam membeberkan suatu peristiwa, portal media akan melampirkan fakta-fakta yang ada. Terkait dengan hal tersebut terdapat dua dimensi besar dalam framing Entman yaitu, mengenai seleksi isu dan penonjolan aspek-aspek tertentu.

\section{Analisis Framing Dua Dimensi Menurut Robert M. Entman}

\section{Seleksi Isu}

Pada analisis seleksi isu ini, berita dari Tirto.id cenderung lebih menampilkan isu mengenai faktafakta yang mengarah dalam ranah kritik terhadap kinerja pemerintah. Narasumber dalam ketiga berita dari Tirto.id antara lain, Presiden Jokowi, Kepala Badan Kebijakan Fiskal Kementerian Keuangan (BKF Kemenkeu) Febrio Kacaribu, Menteri Keuangan Sri Mulyani Indrawati, Menteri Koordinator Bidang Perekonomian Airlangga Hartarto, Direktur Riset Center of Reform on Economics (Core) Piter Abdullah, Ketua KSPI Kahar S Cahyono, Kepala Bappenas Suharso Monoarfa, serta Peneliti Institute for Development of Economics and Finance (Indef) yaitu Heri Firdaus.

Pada ketiga berita tersebut, peneliti juga melihat fakta-fakta yang dimasukkan dan dikeluarkan oleh Tirto.id, pertama yaitu fakta yang dimasukkan antara lain, pernyataan dari Badan Perencanaan dan Pembangunan Nasional (Bappenas) misalnya mencatat jumlah pengangguran sudah bertambah 3,7 juta orang selama pandemi. Angkanya mungkin sekarang lebih banyak. Pada 2020 Bapennas memperkirakan tingkat pengangguran terbuka (TPT) menyentuh 8,1 hingga 9,2\% melompat dari posisi 2019 yang berkisar $5,28 \%$. Kepala Bappenas Suharso, mengatakan pemerintah akan berupaya memitigasi lonjakan pengangguran dengan mengincar pemulihan sektor manufaktur sehingga bisa kembali menciptakan lapangan kerja.

Kemudian terdapat fakta mengenai bantuan pemerintah terhadap pekerja di Indonesia, dari pernyataan Jokowi yaitu mengenai bantuan BLT kepada para pekerja bergaji di bawah Rp5 juta, dengan dasar data milik Badan Penyelenggara Jaminan Sosial (BPJS) sebesar Rp.2,4 juta selama empat bulan, dalam sebulan akan mendapat Rp.600 ribu, namun program tersebut sempat tertunda atau terlambat, sehingga efektifitas program tersebut juga sempat di pertanyakan publik salah satunya, Ketua Departemen Komunikasi dan Media Konfederasi Serikat Pekerja Indonesia (KSPI) Kahar S Cahyono, lalu Direktur Riset Center of Reform on Economics (Core) Piter Abdullah juga menyatakan lambannya PEN untuk korporasi menunjukkan keanehan sistem penyelamatan ekonomi Indonesia. Bansos pemerintah pusat sempat terlambat diterima warga karena hal sepele, yaitu kemasannya, yang bertuliskan "Bantuan Presiden," habis. 
Pada ketiga berita Tirto.id tersebut lebih menekankan pada isu fakta-fakta kenaikan angka pengangguran, disini Tirto.id menampilkan sisi pro dan kontra terhadap isu kinerja pemerintah dalam menanggulangi angka PHK dan pengangguran di Indonesia. Namun yang lebih terlihat yaitu sisi kontra, dengan memasukkan pernyataan yang dilayangkan oleh ketua KSPI, dan direktur riset Core, dari sisi pro Tirto.id memasukkan pernyataan dari Kepala Bappenas mengenai upaya pemerintah dalam mengatasi permasalahan tersebut.

Sementara itu, dalam berita CNN Indonesia juga memaparkan fakta-fakta mengenai kasus PHK dan langkah pemerintah. Narasumber dari kedua berita CNN Indonesia antara lain, Menteri Ketenagakerjaan Ida Fauziah, Kepala Badan Perencanaan Pembangunan Nasional (Bappenas) Suharso Monoarfa, Ekonom Bank Permata Josua Pardede, Ekonom CORE Indonesia Piter Abdullah.

Adapun fakta-fakta yang ditampilkan melalui pernyataan dari berita pertama yaitu data Badan Pusat Statistik (BPS) mencatat jumlah pengangguran sekitar 6,88 juta pada Februari 2020, sementara menteri Ida Fuziah mengatakan data rinci mengenai tenaga kerja yang terkena masalah PHK di masa pandemi belum sepenuhnya lengkap, sehingga permasalahan tersebut berpotensi membuat angka pengangguran meningkat. Dalam berita pertama oleh CNN Indonesia ini, Kementerian Ketenagakerjaan menyatakan jalan keluar dengan cara mendorong kewirausahaan demi memperluas kesempatan kerja di dalam negeri.

Selanjutnya berita kedua yang menampilkan fakta-fakta antara lain, setiap korban PHK mendapatkan bantuan pelatihan dan dana tunai melalui program Kartu Prakerja, dari sisi manfaat bantuan tersebut menolong setiap pesertanya untuk waktu yang lama dan tak hanya memberikan uang, tapi juga pelatihan. Dalam CNN Indonesia Ekonom CORE Indonesia Piter Abdullah berpendapat BLT bagi pekerja bergaji di bawah Rp.5 juta bukan hanya membantu karyawan tapi juga perusahaan, karena mayoritas perusahaan telah memotong gaji karyawan, sehingga bantuan dari pemerintah tersebut membantu perusahaan dalam menutup potongan gaji tersebut.

Dari kedua berita CNN Indonesia tersebut yang cukup terlihat yaitu lebih dominan dari sisi pro terhadap kinerja pemerintah dalam menanggulangi kasus PHK saat masa pandemi ditinjau dari pern yataan yang dimasukkan oleh CNN Indonesia tersebut. Melalui pernyataan, menteri Ida Fauziah tentang permasalahan data rinci korban PHK yang dilanjutkan dengan memberi solusi, selain itu dalam berita kedua, Piter Abdullah menjelaskan mengenai manfaat dari program BLT bagi pekerja.

\section{Penonjolan Aspek}

Pada analisis ini memperlihatkan aspek-aspek yang menonjol berupa pemilihan kata atau kalimat dalam judul, visualisasi gambar yang ditayangkan, dan penngunaan kalimat penegas di dalam isi berita. Dari penonjolas aspek, kita dapat menhgetahui perbedaan framing pada isu yang sama pada dua portal yang berbeda, bagaimana suatu portal berita membingkai kejadian atau peristiwa, sehingga akan terlihat keberpihakan atau tidaknya portal berita.

Terdapat penonjolan aspek berupa kalimat pernyataan berupa kritik mengenai lambannya program bantuan dari pemerintah, pada bagian judul berita Tirto.id, "Berbagai Insentif Jokowi Saat Pandemi yang Telat dan Kurang Tepat", selanjutnya pada bagian isi teks terdapat penonjolan aspek berupa kalimat, "Ada banyak insentif yang diberikan pemerintah saat masa pandemi. Beberapa di antaranya terlambat cair, lainnya dianggap tak tepat sasaran" (pada berita berjudul : Berbagai Insentif Jokowi Saat Pandemi yang Telat dan Kurang Tepat). 
ISSN. 2442-6962

Vol. 10. No. 1 (2021)

Pada berita milik Tirto.id menjelaskan bahwa program yang dibuat pemerintah mengalami kendala sehingga membuat program tersebut terlambat, dan beberapa diantaranya tidak tepat sasaran, salah satunya masalah dipihak daerah masing-masing. Pemerintah diharap untuk dapat memperbaiki sistem penyebaran bantuan terhadap korban PHK maupun program BLT tersebut, karena jika tidak segera ditangani, tingkat pengangguran dan korban PHK di Indonesia akan terus mengalami pelonjakan.

Adapun kata yang sering muncul dalam berita tersebut yaitu, korban PHK, lambannya, lonjakan, pengangguran, program BLT \& prakerja, efektifitas, dan pemerintah. Tirto.id dalam beberapa beritanya lebih sering menggunakan gambar presiden Jokowi, yang berarti sebagai aktor utama.

Tabel 1

Penonjolan Aspek Dalam Berita Tirto.id

\begin{tabular}{|l|l|}
\hline No & Gambar dan Judul Berita \\
\hline 1. & \\
\hline 2. & \\
yang Bisa Dilakukan Jokowi? & \\
Angka Pengangguran 2020 Terburuk, Apa \\
3.
\end{tabular}


Sama halnya dengan Tirto.id, CNN Indonesia dalam beritanya mengenai isu tersebut menggunakan kalimat yang bermakna kritik terhadap kinerja pemerintah, salah satunya yaitu pada judul beritanya "Setelah Beri BLT Pekerja, Jokowi Perlu Revisi Kartu Prakerja" terlebih penekanan tersebut terdapat dalam isi berita berupa kalimat pernyataan dari Ekonom CORE Indonesia Piter Abdullah "Pemerintah seharusnya tegas, yang harus dibantu dulu yang terkena PHK. Bukan yang baru lulus kuliah. Kalau baru lulus kuliah rata-rata masih di bawah tanggung jawab orang tua, kalau yang terkena PHK sudah punya anak dan istri," (dalam berita : Setelah Beri BLT Pekerja, Jokowi Perlu Revisi Kartu Prakerja)

Dalam berita CNN Indonesia juga terdapat kata yang sering muncul sebagai tanda penekanan atau penonjolan isu yang ditampilkan oleh pihak CNN Indonesia, kata yang seirng muncul antara lain, pemerintah, program bantuan, pekerja, peningkatan, dirumahkan, korban PHK, kartu prakerja, merevisi, dan kelemahan. CNN Indonesia dalam beritanya mengenai masalah tersebut menggunakan gambar uang sebagai bentuk dari bantuan pemerintah, di berita lain CNN Indonesia menggunakan gambar orang yang sedang berjalan pulang, gambar tersebut sebagai ilustrasi pekerja yang menjadi korban PHK.

Tabel 2

\section{Penonjolan Aspek Berita CNN Indonesia}

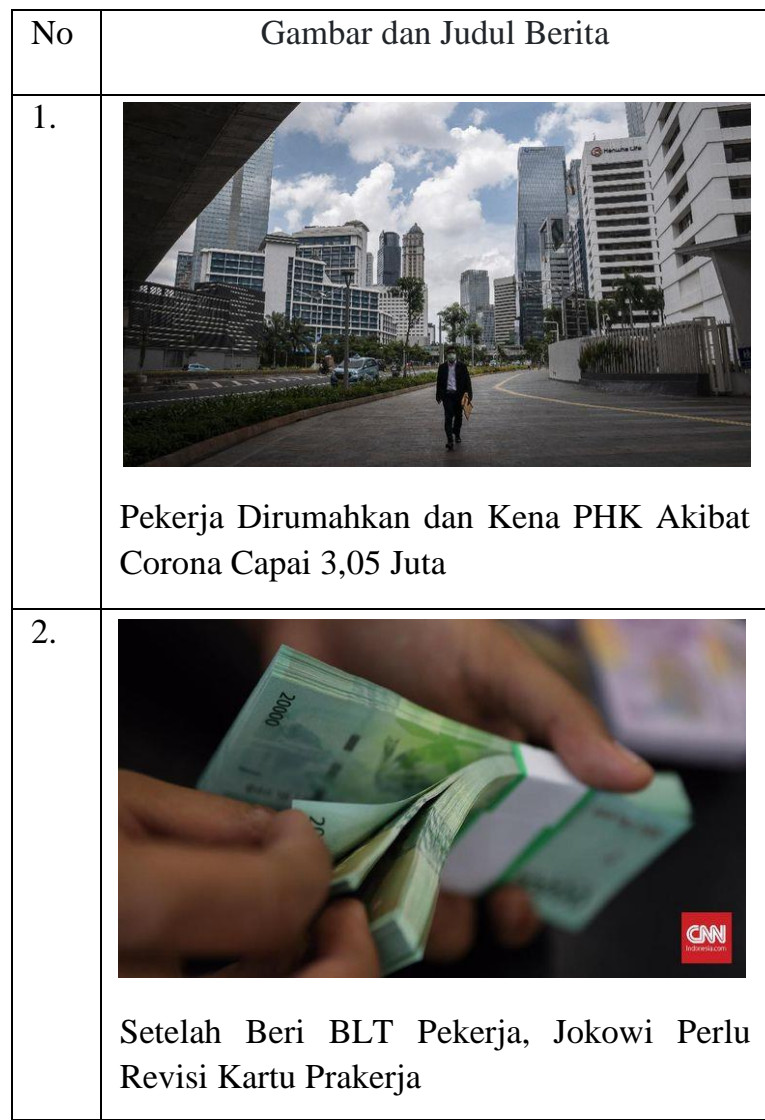

Pada kedua portal berita online, baik Tirto.id maupun CNN Indonesia yang membahas mengenai efektivitas kinerja pemerintah dalam kasus PHK, menilai kinerja berupa program bantuan dari pemerintah terbilang lamban dan kurang tepat sasaran. 
JISIP: Jurnal Ilmu Sosial dan Ilmu Politik

ISSN. 2442-6962

Vol. 10. No. 1 (2021)

\section{Analisis Framing Robert M. Entman Empat Elemen}

Pemberitaan mengenai kinerja pemerintah dalam menangani angka kasus PHK pada masa pandemi dari kedua portal berita tersebut, baik Tiro.id maupun CNN Indonesia melihat bahwa masalah tersebut sebagai masalah mekanisme, dimana pemerintah sebagai aktor utama yang dinilai lamban dalam menjalankan program bantuan terhadap korban PHK, yang ditinjau dari tertundanya program tersebut dijalankan.

Jika ditinjau dari pemilihan narasumber, pernyataan yang ditampilkan dalam teks berita beserta penonjolan aspek yang ditunjukkan, Tirto.id memperlihatkan sisi positif dan negatif dari masalah tersebut, namun yang cukup terlihat yaitu sisi negatif dari pernyataan dan juga kritik yang dimasukkan dalam isi beritanya. Artinya Tirto.id memperlihatkan keberpihakannya terhadap suatu pihak, namun juga tak menutup kemungkinan untuk memerlihatkan sisi positif dari masalah tersebut.

Tirto.id mengemas berita mengenai kinerja pemerintah dalam menanggulangi korban PHK di masa pandemi dari sisi pro dan kontra. Dari sisi pro terlihat dalam pernyataan Kepala Bappenas Suharso yaitu, Pemerintah akan berupaya memitigasi lonjakan pengangguran dengan mengincar pemulihan sektor manufaktur sehingga bisa kembali menciptakan lapangan kerja. Menteri Keuangan Sri Mulyani, mengatakan akan berfokus pada pemulihan ekonomi di 2021. Beberapa langkahnya sudah dimulai dengan pelonggaran PSBB mulai Juni 2020 dan penggelontoran program Pemulihan Ekonomi Nasional (PEN) senilai Rp. 589,65 triliun.

Namun disisi kontra Tirto.id memasukkan cukup banyak pernyataan dari berbagai pihak, Tirto.id sendiri mengeluarkan pernyataan bahwa ada banyak insentif yang diberikan pemerintah saat masa pandemi, namun beberapa di antaranya terlambat dan dianggap tak tepat sasaran. Hal tersebut juga di tegaskan oleh Piter Abdullah menjelaskan lambannya PEN untuk korporasi menunjukkan keanehan sistem penyelamatan ekonomi Indonesia, seharusnya penyelamatan korporasi yang pertama dilakukan sejak jauh hari, sebab dapat menghindari pemutusan hubungan kerja. Di sisi lain, angkatan kerja baru berpotensi tak terserap dan menurut Kemnaker ada tambahan 2 juta orang tiap tahun dan jumlah lowongan kerja terus menyusut hingga $62 \%$ per Mei 2020.

Sama halnya dengan Tirto.id, CNN Indonesia juga memperlihatkan sisi pro dan kontra dalam isi bahasanya, yang ditinjau dari segi visualisasi gambar, judul, dan pernyataan yang dimasukkan dalam isi beritanya. Namun disisi ini CNN Indonesia cukup imbang antara pernyataan positif dan negatifnya. Artinya CNN Indonesia tidak berpihak disatu sisi.

CNN Indonesia dalam mengemas berita mengenai masalah tersebut dari sisi pro dan kontra. Namun yang lebih terlihat yaitu sisi pro. melalui pernyataan Menteri ketenagakerjaan Ida Fauziah yaitu, mulai 2021 akan melaksanakan program kewirausahaan yang terintegrasi dan berkelanjutan sehingga bisa secara efektif membentuk wirausaha-wirausaha baru dan meningkatkan wirausaha rintisan, selanjutnya Ekonom CORE Indonesia Piter Abdullah menyatakan program BLT bagi pekerja bergaji di bawah Rp.5 juta bukan hanya membantu karyawan tapi juga perusahaan, karena bantuan tersebut membantu perusahaan dalam menutup potongan gaji yang sebelumnya telah dilakukan pihak perusahaan akibat penurunan omset di masa pandemi.

Sedangkan dari sisi kontra dilihat dalam pernyataan Ekonom CORE Indonesia Piter Abdullah mengenai kartu prakerja, dimana pemerintah seharusnya tegas, yang seharus dibantu terlebih dahulu yaitu 
ISSN. 2442-6962

Vol. 10. No. 1 (2021)

mereka yang terkena PHK, bukan yang baru lulus kuliah, karena mereka yang terkena PHK sebagian besar telah berkeluarga.

Tabel 3

Perbandingan Empat Elemen Framing Robert M. Entman pada Tirto.id dan CNN Indonesia

\begin{tabular}{|c|c|c|}
\hline Elemen Framing & Tirto.id & CNN Indonesia \\
\hline $\begin{array}{c}\text { Define problems } \\
\text { (mendefinisikan } \\
\text { masalah) }\end{array}$ & $\begin{array}{lll}\text { Masalah } & \text { Mekanisme } & \text { Program } \\
\text { Bantuan } & & \\
\end{array}$ & $\begin{array}{lll}\text { Masalah } & \text { Mekanisme } & \text { Program } \\
\text { Bantuan } & & \end{array}$ \\
\hline $\begin{array}{c}\text { Diagnose causes } \\
\text { (memperkirakan } \\
\text { masalah atau sumber } \\
\text { masalah) }\end{array}$ & $\begin{array}{l}\text { Mekanisme dari program BLT dan } \\
\text { Prakerja yang lamban, sempat } \\
\text { tertunda dan tak tepat sasaran } \\
\text { terutama di daerah kecil, sehingga } \\
\text { lapangan pekerjaan terus menurun. }\end{array}$ & $\begin{array}{l}\text { Mekanisme program kartu prakerja } \\
\text { yang kurang tepat sasaran karena } \\
\text { lebih mendahulukan fresh graduate, } \\
\text { dibandingkan korban PHK. }\end{array}$ \\
\hline $\begin{array}{c}\text { Make moral judgement } \\
\text { (membuat keputusan } \\
\text { moral) }\end{array}$ & 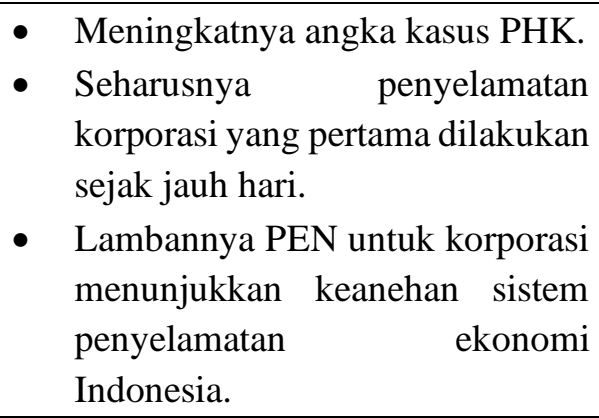 & $\begin{array}{l}\text { - Meningkatnya angka kasus PHK. } \\
\text { - Program BLT dari pemerintah } \\
\text { tidak hanya membantu karyawan } \\
\text { namun juga perusahaan. } \\
\text { - Program kartu prakerja kurang } \\
\text { tepat sasaran. }\end{array}$ \\
\hline $\begin{array}{c}\text { Treatment } \\
\text { Recommendation } \\
\text { (menekankan } \\
\text { penyelesaian) }\end{array}$ & $\begin{array}{l}\text { Pemerintah akan berupaya memitigasi } \\
\text { lonjakan-lonjakan pengangguran } \\
\text { dengan mengincar pemulihan sektor } \\
\text { manufaktur sehingga bisa kembali } \\
\text { menciptakan lapangan kerja. }\end{array}$ & $\begin{array}{l}\begin{array}{l}\text { Mulai tahun depan } \\
\text { ketenagakerjaan akan }\end{array} \begin{array}{r}\text { Menteri } \\
\text { segera }\end{array} \\
\text { melaksanakan suatu program } \\
\text { kewirausahaan yang terintegrasi dan } \\
\text { berkelanjutan sehingga bisa secara } \\
\text { efektif membentuk wirausaha- } \\
\text { wirausaha baru dan meningkatkan } \\
\text { wirausaha rintisan. }\end{array}$ \\
\hline
\end{tabular}

\section{KESIMPULAN}

Dari hasil penelitian mengenai bagaimana kedua portal berita membingkai atau frame isu terkait kinerja pemerintah dalam menanggulangi angka korban PHK di masa pandemi dengan mengambil berita dari portal berita online Tirto.id dan CNN Indonesia. Ditinjau dari bagaimana kdeua portal berita tersebut memilih narasumber dan pernyataan yang dilontarkan, serta penonjolan aspek yang ditunjukkan, keduanya memasukkan sisi positif dan negatif, dan menarik kesimpulan bahwa kinerja pemerintah dalam hal ini kurang efektif, dapat dilihat dari program BLT maupun kartu prakerja mengalami keterlambatan dan kurang tepat sasaran. 
JISIP: Jurnal Ilmu Sosial dan Ilmu Politik

ISSN. 2442-6962

Vol. 10. No. 1 (2021)

Namun kecenderungan kedua portal berita memiliki perbedaan, dimana Tirto.id lebih cenderung menampilkan sisi negatif dan memasukkan kritik dari pernyataan narasumbernya, walaupun CNN Indonesia dalam beritanya juga menampilkan sisi negatif atas program pemerintah, tetapi lebih banyak memasukkan hal positif dan membahas mengenai manfaat dari program tersebut. Dari hasil analisis framing kedua portal berita online tersebut dapat disimpulkan bahwa adanya program bantuan dari pemerintah memberikan dampak positif, tetapi mekanisme dari program tersebut perlu ditindaklanjuti oleh pemerintah.

\section{DAFTAR PUSTAKA}

Abrori. (2017). Analisis framing Robert N Entman atas pemberitaan kasus kekerasan terhadap aktivis dan jurnalis pada majalah Mata Madura edisi ke-7, tanggal 3-16 oktober 2016. Undergraduate thesis, UIN Sunan Ampel Surabaya.

Al Imran, M. (2014). Efektivitas Kinerja Badan Narkotika Nasional Provinsi Sulawesi Selatan dalam Upaya Pencegahan dan Pemberantasan Narkotika Di kalangan Remaja Kota Makassar. UniversitasHasanuddin Makassar.

Binti, Miftahul Mahmudah. (2018). SANDIAGA UNO DALAM BINGKAI BERITA (Analisis Framing Kemacetan Tanah Abang pada Media Online CNNIndonesia.com dan Kompas.com edisi 06 dan 07 November 2017). Skripsi (S1) thesis, Universitas Muhammadiyah Ponorogo.

CNN Indonesia : Pekerja Dirumahkan dan Kena PHK Akibat Corona Capai 3,05 Juta.https://www.cnnindonesia.com/ekonomi/20200720114203-92-526610/pekerja-dirumahkan-dankena-phk-akibat-corona-capai-305-juta

CNN Indonesia : Setelah Beri BLT Pekerja, Jokowi Perlu Revisi Kartu Prakerja. https://www.cnnindonesia.com/ekonomi/20200827064857-532-539735/setelah-beri-blt-pekerjajokowi-perlu-revisi-kartu-prakerja

Maryani, C., \& Indah, S. (2020). Framing Berita Media Online tentang Dugaan Eksploitasi Anak pada Calon Atlet Bulu Tangkis PB Djrarum. Universitas Budi Luhur Jakarta.

DEDEK, FERDIAN. (2018). ANALISIS FRAMING BERITA PENYIRAMAN AIR KERAS TERHADAP NOVEL BASWEDAN DI MEDIA ONLINE DETIK.COM. Skripsi thesis, Universitas Islam Negeri Sultan Syarif Kasim Riau.

Efa, Nopita (2015) HUBUNGAN GAYA KEPEMIMPINAN TRANSFORMASIONAL DENGAN EFEKTIVITAS KINERJA (PADA KARYAWAN AKADEMIK UIN SUSKA RIAU). Skripsi thesis, Universitas Islam Negeri Sultan Syarif Kasim Riau.

Eriyanto, (2002) Analisis Framing (Kontruksi, Ideologi, dan Politik Media). Yogyakarta.

Erawati, I., Darwis, M., \& Nasrullah, M. (2017). Efektivitas Kinerja Pegawai pada Kantor Kecamatan Pallangga Kabupaten Gowa. Jurnal Office, 3(1), 13-18.

Hadian, D., \& Suharyani, Y. (2014). Pengaruh Motivasi, Komunikasi, Dan Kompetensi Dari Efektivitas Kinerja Aparatur Serta Dampaknya Terhadap Efektivitas Organisasi Badan Koordinasi Promosi Dan Penanaman Modal Daerah Provinsi Jawa Barat. Jurnal Ekonomi, Bisnis \& Entrepreneurship, 8(1), 114. 
JISIP: Jurnal Ilmu Sosial dan Ilmu Politik

ISSN. 2442-6962

Vol. 10. No. 1 (2021)

Kusnan, A. (2005). Analisis Sikap Iklim Organisasi, Etos Kerja dan Disiplin Kerja dalam Menentukan Efektivitas Kinerja Organisasi di Garnisun Tetap III Surabaya (Doctoral dissertation, UNIVERSITAS AIRLANGGA).

Kusmayani, N. (2006). TINJAUAN MENGENAI SISTEM PEMUTUSAN HUBUNGAN KERJA KARYAWAN PADA PT. ASURANSI JASA INDONESIA (JASINDO) KANTOR CABANG SUPRATMAN BANDUNG. Doctoral dissertation. Universitas Widyatama.

Morissan. (2010). Komunikasi Media : Media, Budaya, dan Masyarakat. Ghalia Indonesia.

Romli, A. S. M. (2012). Jurnalistik Online: Panduan Mengelola Media Online. Nuansa Cendekia.

Setiawan, Agung (2012) KONSTRUKSI PEREMPUAN DALAM MEDIA MASSA (Analisis Framing Pada Kolom For Her Harian Jawa Pos Edisi 30 Maret. 6,13, 20 April. 28 September dan 19 Oktober 2011). Other thesis, University of Muhammadiyah Malang.

Sobur Alex. (2013). Semiotika Komunikasi. Bandung: Remaja Rosdakarya.

Tirto.id : Angka Pengangguran 2020 Terburuk, Apa yang Bisa Dilakukan Jokowi? https://tirto.id/angkapengangguran-2020-terburuk-apa-yang-bisa-dilakukan-jokowi-fKQg

Tirto.id : Dampak COVID-19, Airlangga: Korban PHK Indonesia Naik Jadi 2,1 Juta. https://irto.id/dampak-covid-19-airlangga-korban-phk-indonesia-naik-jadi-21-juta-fXp7

Tirto.id : Berbagai Insentif Jokowi Saat Pandemi yang Telat dan Kurang Tepat. https://tirto.id/berbagaiinsentif-jokowi-saat-pandemi-yang-telat-dan-kurang-tepat-f2yu

Wahyudi, Arif (2017) KONSTRUKSI REALITAS BERITA INFOTAINMENT (Analisis Framing Rubrik Infotainment Kompas.com dan JPNN.com edisi 10-15 Oktober 2016). Other thesis, University of Muhammadiyah Malang.

Wijayanto, K. A. (2007). PRAKTEK PEMUTUSAN HUBUNGAN KERJA BERDASAR UNDANGUNDANG KETENAGAKERJAAN NO. 13 TAHUN 2003 DI PT. DELTA MERLIN DUNIA TEXTILE KARANGANYAR. (Doctoral dissertation, Universitas Muhammadiyah Surakarta). 